\begin{tabular}{lllll}
\hline Nova Hedwigia & $\mathbf{8 9}$ & $3-4$ & $355-360$ & Stuttgart, November 2009 \\
\hline
\end{tabular}

\title{
A new species of Protoparmelia (lichenized Ascomycota) from Australia
}

\author{
by \\ John A. Elix ${ }^{1}$ and Gintaras Kantvilas ${ }^{2}$ \\ ${ }^{1}$ Research School of Chemistry, Building 33, Australian National University, \\ Canberra, ACT 0200, Australia \\ ${ }^{2}$ Tasmanian Herbarium, Private Bag 4, Hobart, Tasmania 7001, Australia
}

With 1 figure

Elix, J.A. \& G. Kantvilas (2009): A new species of Protoparmelia (lichenized Ascomycota) from Australia. - Nova Hedwigia 89: 355-360

Abstract: The new species, Protoparmelia nebulosa Elix \& Kantvilas, based on material from Western Australia and New South Wales, is described. It is characterized chiefly by an isidiate thallus, and by the presence of constipatic, isomyelochroic, myelochroic and protoconstipatic acids. The Australasian species, P. pulchra Diederich, Aptroot \& Sérus., is recorded from Tasmania for the first time.

Key words: Australia, fatty acids, lichens, Tasmania, taxonomy.

\section{Introduction}

Protoparmelia M.Choisy is a cosmopolitan genus with approximately 25 species recognized worldwide (Farr \& Rossman 2009, Robert et al. 2009). It is characterized by a crustose thallus, typically with a cortex of anticlinal hyphae, a coccal green photobiont, lecanorine apothecia with a meristematic proper excipulum, eight-spored asci approximating to the Lecanora-type (after Hafellner 1984, Aptroot et al. 1997a), with a well-developed amyloid tholus with or without an ocular chamber but always with a distinct, non-amyloid masse axiale, sparsely branched paraphyses, and simple (rarely 1-septate when old), hyaline, narrowly ellipsoidal to oblong ascospores, $7-17 \times 2-7 \mu \mathrm{m}$. It is superficially similar to Lecanora but separated from that genus by the grey-brown to reddish-brown thallus, the generally smaller, narrower ascospores and straight conidia. The structure of the excipulum is similar to that found in the family Parmeliaceae (Henssen 1995) and, as a result, Protoparmelia has been included in that family by various authors (e.g. Miyawaki 1991, Aptroot et al. 1997a, Eriksson 2005). Although recent molecular investigations have supported the close relationships 
between Protoparmelia and the Parmeliaceae, its inclusion there remains unresolved and requires further investigation (Arup et al. 2007; Crespo et al. 2007).

Species of Protoparmelia typically grow on bark, decorticated wood and rocks in tropical, temperate or alpine habitats; some species may also be lichenicolous. There has been no comprehensive revision of the genus but the literature pertaining to it is not insignificant. This includes an account of the chiefly lichenicolous species related to Protoparmelia atriseda (Fr.) R.Sant \& V.Wirth by Poelt and Leuckert (1991), regional treatments for the British Isles (Coppins 1992), the Himalayas (Poelt \& Grube 1992), the Sonoran Desert (Ryan et al. 2004) and North America (Brodo \& Aptroot 2005), and the description of new species from Papua New Guinea (Aptroot et al. 1997a), Europe (Aptroot et al. 1997b), North America (Lendemer \& Lumbsch 2008) and Australia (Elix 2008).

Four species of Protoparmelia are currently known from Australia (McCarthy 2009, Elix 2009): three occur in tropical to warm temperate regions of the Northern Territory, Queensland and northern New South Wales (P. isidiata Diederich, Aptroot \& Sérus., $P$. pulchra Diederich, Aptroot \& Sérus. and P. rogersii Elix), whereas the cosmopolitan $P$. badia is known from alpine areas of New South Wales, Victoria and Tasmania (Elix 2009). A further taxon is described here from mainland Australia, and a second species is recorded for Tasmania.

\section{Material and methods}

Observations on thallus and apothecial morphology were undertaken using light microscopy on hand cut sections mounted in water, $10 \% \mathrm{KOH}$ and dilute Lugol's Iodine. Chemical constituents were identified by thin layer chromatography (Culberson 1972, Culberson et al. 1981, Elix \& ErnstRussell 1993), where necessary confirmed by high performance liquid chromatography (Elix et al. 2003) and comparison with authentic samples.

\section{Results}

Protoparmelia nebulosa Elix \& Kantvilas sp. nov.

Mycobank NO. MB513320

Protoparmeliae isidiatae similis sed ascosporis brevioribus et acida aliphatica continenti differt.

TyPE: Australia, Western Australia, Brookton Highway Nature Reserve, Darling Plateau, 25 km W of Brookton, 32 $233^{\prime} 50^{\prime \prime S}, 116^{\circ} 44^{\prime} 03 " \mathrm{E}, 285 \mathrm{~m}$ alt., on dead wood in Eucalyptus woodland with laterite outcrops, 5 Apr. 2006, J.A.Elix 38722 (PERTH, holotype; CANB, HO - isotypes).

Thallus whitish, pale brown, grey-brown, red-brown or dark brown, thin, smooth and continuous, soon becoming cracked and areolate, with the areoles irregularly shaped, $0.3-0.8 \mathrm{~mm}$ wide, contiguous or scattered, \pm flat to weakly convex, isidiate. Isidia common, laminal, subglobose to cylindrical, not or sparingly branched, often rather gnarled, up to $0.5 \mathrm{~mm}$ high, with a darker brown apex, at length \pm dominating the whole appearance of the thallus. Prothallus sometimes present, marginal, dark brown. Photobiont a unicellular green alga with cells globose, (7-)10-15 $\mu \mathrm{m}$ diam., forming a continuous layer 80-100 $\mu \mathrm{m}$ thick. Upper and lower cortex not developed. 


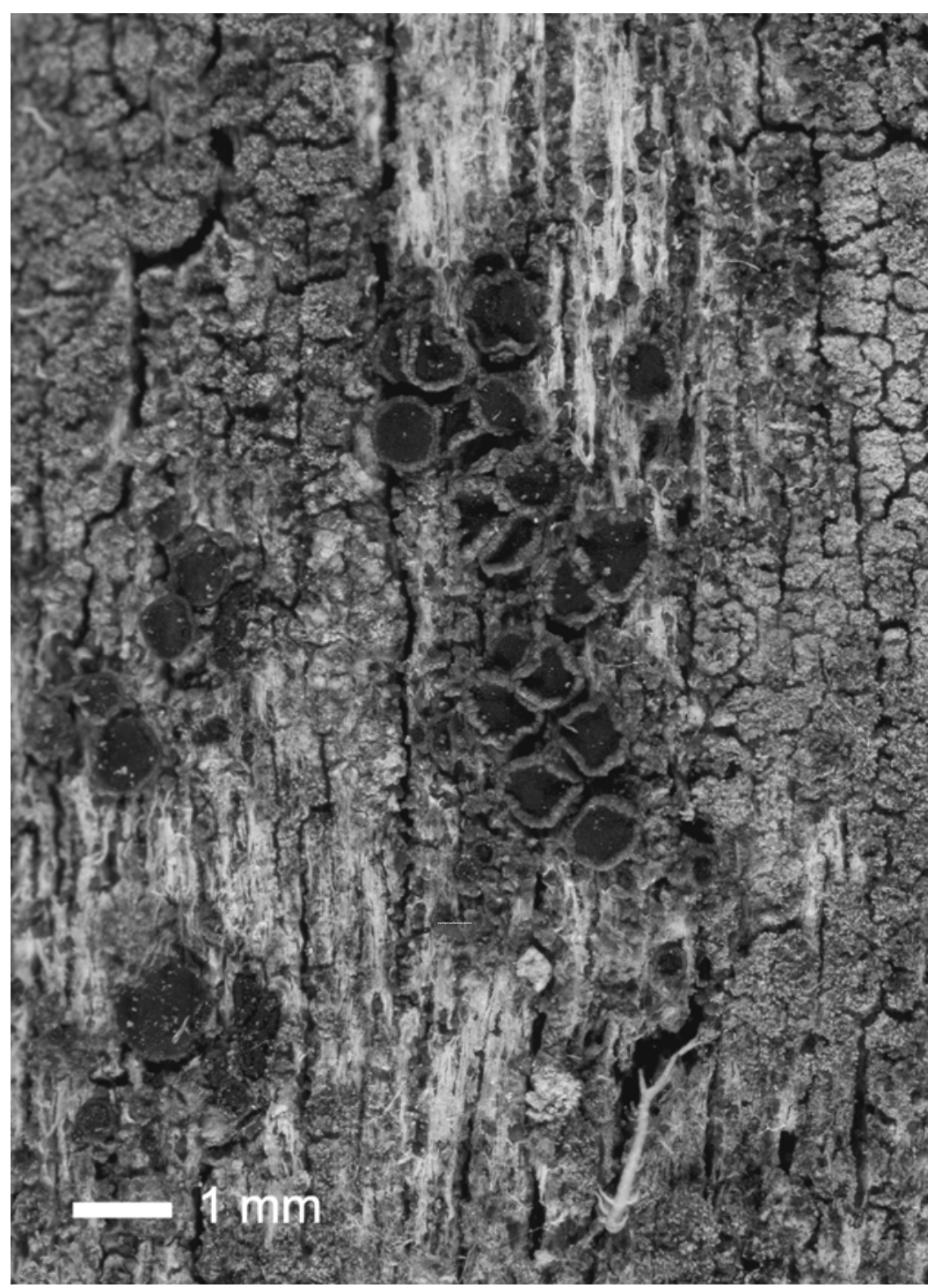

Fig. 1. Protoparmelia nebulosa (part of holotype in PERTH).

Medulla white, non-amyloid, composed of branched, short-celled hyphae 3-4 $\mu \mathrm{m}$ wide. Apothecia lecanorine, sessile, \pm constricted at the base, round, 0.6-2.0 mm diam., glossy; disc pale to dark reddish or orange-brown or dark brown, \pm plane or weakly convex, usually darker than the margin, epruinose; thalline excipulum \pm undulate, pale, whitish to pale brownish, prominent and usually persistent, $12-50 \mu \mathrm{m}$ thick, sometimes slightly curved over the disc, sometimes radially striate; proper exciplum \pm inconspicuous and poorly delimited, cupulate, in section hyaline, 5-10 $\mu \mathrm{m}$ 
thick. Hypothecium pale to deep red-brown, 40-70 $\mu \mathrm{m}$ tall, unchanged in $\mathrm{K}$. Hymenium colourless to pale yellow, unchanged in K, 30-50 $\mu \mathrm{m}$ thick, IKI+ blue, persistently coherent, not inspersed, overlain by a brown to yellow-brown or olivebrown epihymenium 7-10 $\mu \mathrm{m}$ tall, likewise unchanged in K. Paraphyses short and robust, branched near the tips, rarely anastomosing, septate, 3-5 $\mu \mathrm{m}$ wide; apical cells not markedly swollen, lacking a gelatinous cap and unpigmented. Asci $(28-) 30-35(-42) \times 10-13 \mu \mathrm{m}, 8$-spored, clavate, approximating the Lecanora-type: tholus amyloid, penetrated entirely by a narrow, cylindrical to occasionally \pm barrelshaped, non-amyloid masse axiale; ocular chamber lacking or blunt. Ascospores simple (rarely 1 -septate when old), colourless, narrowly ellipsoidal, \pm mono- to pentaguttulate, non-halonate, $10-13 \times 2.0-3.5 \mu \mathrm{m}$. Pycnidia not seen.

Chemistry: Thallus K-, KC-, C-, P-; containing constipatic acid [major], protoconstipatic acid [minor], isomyelochroic acid [major], myelochroic acid [minor], \pm atranorin [minor], \pm lichesterinic acid [minor], \pm placodiolic acid [trace].

Etymology: The specific epithet is derived from the Latin nebulosus (clouded, with unevenly blended colours) in reference to the colour of the upper surface of the thallus.

Notes: Protoparmelia nebulosa most closely resembles $P$. isidiata Diederich, Aptroot \& Sérus. (Aptroot et al. 1997a) and P. hypotremella van Herk, Spier \& Wirth (Aptroot et al. 1997b), all three species being corticolous or lignicolous and having isidia. The three species differ mainly with respect to thallus chemistry: P. isidiata contains alectoronic and dehydroalectoronic acids, $P$. hypotremella contains lobaric acid and congenors, whereas $P$. nebulos $a$ contains a chemosyndrome of fatty acids [constipatic acid and related substances]. Interestingly, a chemical race of the fertile, saxicolous species, Protoparmelia montagnei (Fr.) Poelt \& Nimis, also contains a chemosyndrome of fatty acids (Barbero et al. 2006), related but not identical to that observed in $P$. nebulosa. Morphological differences between the species are found in the isidia, which are granular and gnarled and become eroded in $P$. hypotremella, whereas in $P$. isidiata and $P$. nebulosa, they are subglobose to cylindrical and remain intact. In addition, $P$. hypotremella is invariably corticolous and sterile, whereas the other two species are usually lignicolous and fertile. The ascospores are slightly shorter in $P$. nebulosa [10-13 $\times 2.0-3.5 \mu \mathrm{m}$ versus $9-17 \times 2-3 \mu \mathrm{m}$ in $P$. isidiata] and often distinctly guttulate in $P$. nebulosa [eguttulate in $P$. isidiata]. The three isidiate species also differ in their geographical distribution: $P$. hypotremella is known only from Europe; $P$. isidiata occurs in Papua New Guinea, North America, South America, tropical and subtropical Australia; whereas P. nebulosa is restricted to southern Australia.

The morphology and anatomy of the isidiate species discussed above, and of the non-isidiate $P$. pulchra, suggests that whereas all these lignicolous-corticolous taxa are closely related to each other, they differ somewhat from $P$. badia, the type of the genus. All lack a well-developed cortex, although in each case the thallus is much thinner than that seen in P. badia. Furthermore, in P. badia, the paraphyses are clearly capitate, with the apical cell having a geletinous cap that is typically brownpigmented. In $P$. nebulosa and its relatives, the terminal cell of the paraphyses lacks such a gelatinous cap, is not significantly swollen and is unpigmented. The olive- 
brown to reddish brown epihymenial pigment is diffused through the upper areas of the hymenium and is not confined to the apices of the paraphyses.

At present $P$. nebulosa is known from several localities in Western Australia and from one additional locality in New South Wales. In Western Australia, it grew on dead wood in open Eucalyptus woodland in a region with cool, wet winters and warm, dry summers. Associated species included Hertelidea pseudobotryosa R.C.Harris, Ladd \& Printzen, Hypocenomyce australis Timdal, H. isidiosa Elix, Ochrolechia africana Vain., Parmelina pseudorelicina (Jatta) Kantvilas \& Elix, Ramboldia subnexa (Stirt.) Kantvilas \& Elix and Usnea inermis Motyka. In New South Wales, it likewise grew on dead wood in an open, subalpine Eucalyptus woodland. There some of the more common associated lichen species included Hypogymnia australica Elix, H. pulverata (Nyl.) Elix, Hertelidea aspera (Müll.Arg.) Kantvilas \& Elix, Parmelina pseudorelicina (Jatta) Kantvilas \& Elix, Parmotrema reticulatum (Taylor) M.Choisy, Placynthiella icmalea (Ach.) Coppins \& P.James, Tephromela alectoronica Kalb and Usnea inermis Motyka.

Additional SPecimens examined: New South Wales: Great Dividing Range, Kings Highway, 11 km $\mathrm{E}$ of Bungendore, $810 \mathrm{~m}$ alt., on rotting $\log$ in open Eucalyptus woodland, 5 Jan. 2006, J.A.Elix 36842 (CANB). Western Australia: Boyagin Rock, Boyagin Rock Nature Reserve, $350 \mathrm{~m}$ alt., on dead wood on granite monolith with scattered Eucalyptus and Allocasuarina, 5 Apr. 2006, J.A.Elix 38930 (PERTH, CANB).

\section{New record}

Protoparmelia pulchra Diederich, Aptroot \& Sérus., in A.Aptroot, P.Diederich, E.Sérusiaux \& H.J.M.Sipman, Bibliotheca Lichenologica 64: 147 (1997).

This corticolous species is characterised by the absence of isidia and the presence of alectoronic acid (see Aptroot et al. 1997a for description). It is widely scattered on the Australian mainland and in the high mountains of New Guinea. This is the first report from Tasmania, where it was recorded from the bark of Allocasuarina verticillata in littoral scrub.

Specimen eXamined: Tasmania: Freycinet Peninsula, Sleepy Bay, 4208'S 148 ${ }^{\circ} 19^{\prime} \mathrm{E}, 5 \mathrm{~m}$ alt., 1999 , G.Kantvilas 31/99 (HO).

\section{References}

APTROOT, A., P. DIEDERICH, E. SÉRUSIAUX \& H.J.M. SIPMAN (1997a): Lichens and lichenicolous fungi from New Guinea. - Biblioth. Lichenol. 64: 1-220.

APTROOT, A., P. DIEDERICH, C.M. VAN HERK, L. SPIER \& V. WIRTH. (1997b): Protoparmelia hypotremella, a new sterile corticolous species from Europe, and its lichenicolous fungi. Lichenologist 29: 415-424.

ARUP, U., S. EKMAN, M. GRUBE, J.-E. MATTSSON \& M. WEDIN (2007): The sister group relation of Parmeliaceae (Lecanorales, Ascomycota). - Mycologia 99: 42-49.

BARBERO, M., M. GIRALT, J.A. ELIX, A. GOMEZ-BOLEA \& X. LLIMONA (2006): A taxonomic study of Protoparmelia montagnei (syn. P. psarophana) centered in the Eastern Iberian Peninsula. - Mycotaxon 97: 299-320. 
BRODO, I.M. \& A. APTROOT (2005): Corticolous species of Protoparmelia (lichenized Ascomycotina) in North America. - Canad. J. Bot. 83: 1075-1081.

COPPINS, B.J. (1992): PROTOPARMELIA M. Choisy (1929). In PURVIS, O.W., B.J. COPPINS, D.L. HAWKSWORTH, P.W. JAMES \& D.M. MOORE (eds): The Lichen Flora of Great Britain and Ireland. Natural History Museum Publications \& The British Lichen Society, London: 501-503.

CRESPO, A., H.T. LUMBSCH, J.-E. MATTSSON, O. BLANC, P.K. DIVAKAR, K. ARTICUS, E. WIKLUND, P.A. BAWINGAN \& M. WEDIN (2007): Testing morphology-based hypotheses of phylogenetic relationships in Parmeliaceae (Ascomycota) using three ribosomal markers and the nuclear RPB1 gene. - Mol. Phylog. Evol. 44: 812-824.

CULBERSON, C.F. (1972): Improved conditions and new data for the identification of lichen products by a standardized thin-layer chromatographic method. - J. Chromatogr. 72: 113-125.

CULBERSON, C.F., W.L. CULBERSON \& A. JOHNSON (1981): A standardized TLC analysis of $\beta$-orcinol depsidones. - Bryologist 84: 16-29.

ELIX, J.A. (2008): Four new lichens from tropical and subtropical Australia. - Australas. Lich. 62: 35-39.

ELIX, J.A. (2009): Protoparmelia. - Fl. Austral. 57: 37-40.

ELIX, J.A. \& K.D. ERNST-RUSSELL (1993): A catalogue of standardized thin layer chromatographic data and biosynthetic relationships for lichen substances. - $2^{\text {nd }}$ Edition. Canberra: Australian National University.

ELIX, J.A., M. GIRALT \& J.H. WARDLAW (2003): New chloro-depsides from the lichen Dimelaena radiata. - Biblioth. Lichenol. 86: 1-7.

ERIKSSON, O.E. (ed.) (2005): Outline of Ascomycota - 2005. Myconet 11: 1-113.

FARR, D.F., \& A.Y. ROSSMAN (2009): Fungal Databases, Systematic Mycology and Microbiology Laboratory, ARS, USDA. Retrieved February 6, 2009, from http://nt.ars-grin.gov/fungaldatabases/

HAFELLNER, J. (1984): Studien in Richtung einer natürlicheren Gliederung der Sammelfamilien Lecanoraceae und Lecideaceae. - Beih. Nova Hedwigia 79: 241-371.

HENSSEN, A. (1995): Apothecial structure and development in Protoparmelia badia (Parmeliaceae s. lat.). - In Flechten Follmann. Contributions to Lichenology in Honour of Gerhard Follmann (DANIËLS, F.J.A., M. SCHULZ \& J. PEINE, eds.). Cologne: Geobotanical and Phytotaxonomical Study Group, Botanical Institute, University of Cologne: 55-62.

LENDEMER, J.C. \& H.T. LUMBSCH (2008): Protoparmelia capitata sp. nov. and P. isidiata Diederich, Aptroot \& Sérus., two species of Protoparmelia (Lecanorales, Ascomycota) from southeastern North America. - Lichenologist 40: 329-336.

McCARTHY, P.M. (2009): Checklist of the Lichens of Australia and its Island Territories. Australian Biological Resources Study, Canberra. Version 13 February 2009. http://www.anbg.gov.au/abrs/ lichenlist/introduction.html.

MIYAWAKI, H. (1991): Protoparmelia badia in Japan. - Hikobia 11: 29-32.

POELT, J. \& M. GRUBE (1992): Beiträge zur Kenntnis der Flechtenflora des Himalaya V. Die Gattung Protoparmelia Choisy. - Nova Hedwigia 55: 381-395.

POELT, J. \& C. LEUCKERT (1991): Der Formenkreis von Protoparmelia atriseda (Lichenes, Lecanoraceae) in Europa. - Nova Hedwigia 52: 39-64.

ROBERT, V., G. STEGEHUIS \& J. STALPERS (2009). The MycoBank engine and related databases. Retrieved February 6, 2009. http://www.mycobank.org

RYAN, B.D., T.H. NASH III, \& J. HAFELLNER (2004): Protoparmelia. - In: NASH III, T.H., B.D. RYAN, P. DIEDERICH, C. GRIES \& F. BUNGARTZ (eds.): Lichen Flora of the Greater Sonoran Desert Region, Vol. 2. Lichens Unlimited, Arizona State University, Tempe, Arizona: 425-439.

Received 15 February 2009, accepted in revised form 27 April 2009. 